\title{
Russiske kjernefysiske styrker
}

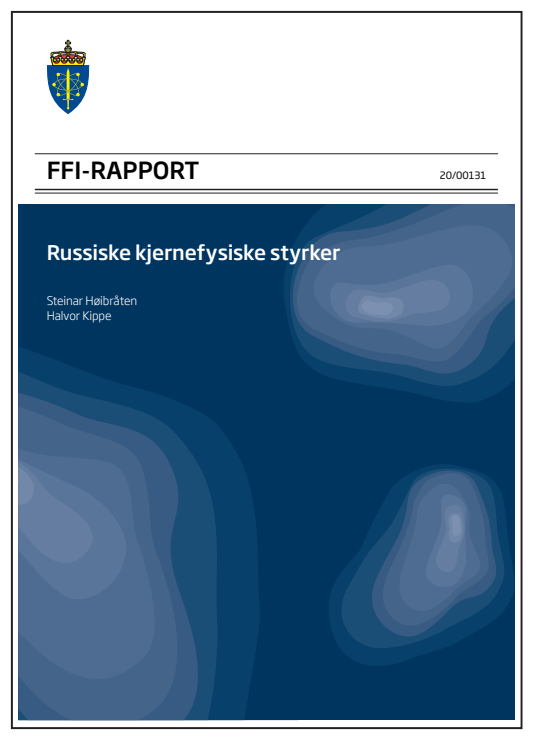

Steinar Høibråten \& Halvor Kippe

Kjeller: Forsvarets forskningsinstitutt 2020

FFI-rapport 20/00131

101 sider. ISBN: 9788246432694

Omtalt av Kristin Ven Bruusgaard [postdoktor, Institutt for statsvitenskap, Universitetet $\mathrm{i}$ Oslo, k.v.bruusgaard@stv.uio.no]

Norge befinner seg i umiddelbar nærhet til verdens største atomstat, Russland, og tett opptil et av Russlands viktigste områder for atomvåpen, Kola-halvøya, med den russiske Nordflåten. Fornyet spenning mellom Russland og Vesten har reist spørsmål om Russland ville vurdere å bruke disse våpnene i en mulig konflikt, samt eventuelt når og hvordan. Russland lover, i sin militærdoktrine, at de kan tenkes å benytte kjernevåpen først i en konvensjonell konflikt som de oppfatter som eksistensiell. Hva betyr dette egentlig - og hvordan kan dette forklare hvorfor Russland beholder et så stort arsenal av kjernevåpen? Særlig Russlands flere tusen substrategiske kjernevåpen som kan brukes fra en rekke ulike plattformer skiller landet fra de aller fleste andre atomstater. Tror Russland de kan utkjempe - og vinne - en krig med kjernevåpen?

Disse spørsmålene gir Russlands kjernefysiske styrker fornyet aktualitet, også for den norske offentligheten. FFI-rapporten Russiske kjernefysiske styrker beskriver i stor detalj hvilke kjernevåpen Russland besitter, og i noen grad hvordan disse er organisert og utplassert. Den diskuterer innledningsvis noen aspekter ved russisk doktrine og strategi, samt forhold knyttet til kommando og kontroll. I de respektive kapitlene tar den for seg russiske landbaserte, sjøbaserte og luftbaserte kjernevåpen, og gir en utfyllende oversikt over kjente våpen og plattformer. Rapporten diskuterer beholdning og kapasitet for produksjon av spaltbart materiale, rustningskontrollavtaler og 
den forventede utviklingen fremover. Rapporten tar systematisk for seg definisjoner, nøkkelkonsept og forkortelser for å lede leseren gjennom øvelsen det er å få oversikt over disse våpensystemene.

Dette er en grundig gjennomarbeidet rapport som gir et meget godt overblikk over russiske kjernefysiske styrker. For en leser som ønsker å sette seg inn i detaljer knyttet til hvert våpensystem - inkludert de nye "fantastiske» våpensystemene president Putin lanserte i sin årlige tale til Den føderale forsamling i 2018 - er dette mat for mons. Rapporten gir faktisk et bedre oversiktsbilde enn andre publikasjoner man kan sammenligne den med. For eksempel gir Bulletin of Atomic Scientists' Nuclear Notebook grundige vurderinger av status og utvikling i kjernevåpenstatenes arsenaler hvert år, men den dekker ikke årlig hvert våpensystem grundig. Det er nødvendig å lese flere årganger av publikasjonen for å danne seg et lignende overblikk over det russiske arsenalet. Det samme kan sies om Military Balance som publiseres av International Institute for Strategic Studies. FFIs Steinar Høibråten og Halvor Kippe har laget et oppslagsverk med sin systematiske fremstilling av Russlands faktiske og mulige kjernevåpen (noen av leveringsplattformene kan bære både konvensjonelle eller kjernefysiske stridshoder).

Samtidig reiser rapporten en rekke spørsmål som forblir uutforsket og kanskje også underkommunisert. Noen lesere vil med stor interesse ta for seg de tekniske detaljene knyttet til hver enkelt type kjernevåpen, som presisjon, ytelse og rekkevidde. Samtidig mangler rapporten refleksjoner knyttet til hvorfor og hvorledes disse våpnene, og den kumulative sammenstillingen av dem, er relevant for et norsk publikum. Hvordan skal vi forstå og forholde oss til «det store omfanget og den store kompleksiteten av det russiske kjernevåpenarsenalet», slik forfatterne beskriver det i sine avsluttende kommentarer? Er det noen av våpensystemene som er mer relevante å bite seg merke i, for et norsk publikum, enn andre? Hvordan står "omfanget og kompleksiteten» seg i forhold til sammenlignbare størrelser - det vil si andre kjernevåpenstater?

Rapporten svarer på et enkelt og åpenbart forskningsspørsmål: Hvilke kjernevåpen har Russland? Men hvordan skal svaret på dette kunne være meningsfylt for en leser uten kompetanse eller innsikt i spørsmål som: Hvorfor har Russland alle disse våpnene, og hvilken hensikt tjener de? Forfatterne skriver i innledningen at de vil diskutere avskrekking, men de nevner ikke i sin diskusjon av doktrine hva eller hvem Russland søker å avskrekke. Forfatterne vektlegger den modernisering som har funnet sted i de russiske kjernefysiske styrkene, men diskuterer ikke utgangspunkt, endepunkt og målsettinger i forhold til sammenlignbare størrelser, som for eksempel USA. Slik rapporten fremstiller det, er Russlands modernisering av egne kjernevåpen langt fremskreden. Men noe av grunnen til at denne moderniseringen fremstår som omfattende og unik, er at amerikanerne ikke har kommet like godt i gang med sin egen meget omfattende modernisering som vil finne sted over de neste par tiår. Uten litt mer utfyllende kontekstuell informasjon står leseren igjen på bar bakke - det vil si, kringsatt av russiske kjernevåpen med rekkevidde som dekker hele 
Norge og Europa. Det er et skremmende bilde - men samtidig et som vi har levd med siden midten av den kalde krigen.

Selv om Russlands kjernefysiske intensjoner ikke er tema i denne rapporten, kunne en kort utgreiing av noen av de spørsmålene det russiske arsenalet reiser hjulpet leseren til å bedre forstå hva det er de leser om, nemlig Russlands ultimate sikkerhetsgaranti. Dette ville også ha bidratt til å gjøre det tydeligere hvorfor Russland for eksempel beholder et stort arsenal av både strategiske og substrategiske kjernevåpen.

Forfatterne reflekterer kort rundt det faktum at den konvensjonelle militærbalansen har konsekvenser for lands kjernevåpenstrategi og -arsenal. Denne problematikken tydeliggjøres for eksempel gjennom beskrivelsene av et økende antall russiske våpensystemer som kan bære både konvensjonelle og kjernefysiske stridshoder. Det forfatterne ikke kommer inn på, men som også er relevant for å forstå kjernevåpnenes rolle i russisk militær strategi, er hvordan russisk doktrine og operasjonskonsepter i økende grad vektlegger hvordan konvensjonelle og kjernefysiske styrker kan virke sammen - også for å avskrekke en motstander, altså uten å bli brukt. Russland har et omfattende og komplekst kjernevåpenarsenal - men de har også et stadig mer omfattende arsenal av konvensjonelle våpen som de også kan og vil bruke til å påvirke en motstander i en mulig konflikt.

Russiske kjernefysiske styrker gir en meget god oversikt over åpent tilgjengelig informasjon om det russiske kjernevåpenarsenalet. "Analogov net", ville man si på russisk: Det finnes ikke en tilsvarende, åpent tilgjengelig sammenstilling på norsk. Rapporten bidrar til klarhet innenfor et fagfelt som er preget av hemmelighold og fragmentert informasjon. For den spesielt interesserte reiser rapporten også en rekke spørsmål omkring hva russiske kjernefysiske styrker betyr for Norge - i fredstid, krise og konflikt. 